\title{
Fire in the Swamp Forest: Palaeoecological Insights Into Natural and Human-Induced Burning in Intact Tropical Peatlands
}

\author{
Lydia E. S. Cole ${ }^{1,2 \star}$, Shonil A. Bhagwat ${ }^{2,3}$ and Katherine J. Willis ${ }^{2,4}$ \\ ${ }^{1}$ School of Geography and Sustainable Development, University of St Andrews, St Andrews, United Kingdom, ${ }^{2}$ Oxford \\ Long-Term Ecology Laboratory, Department of Zoology, University of Oxford, Oxford, United Kingdom, ${ }^{3}$ Department of \\ Geography, Faculty of Social Sciences, The Open University, Milton Keynes, United Kingdom, ${ }^{4}$ St Edmund Hall, University of \\ Oxford, Oxford, United Kingdom
}

OPEN ACCESS

Edited by:

Tom Evans,

Wildife Conservation Society,

United States

Reviewed by:

Tammo Reichgelt,

Lamont Doherty Earth Observatory

(LDEO), United States

Susan Page,

University of Leicester,

United Kingdom

*Correspondence:

Lydia E. S. Cole

lydcole@gmail.com

Specialty section:

This article was submitted to

Tropical Forests,

a section of the journal

Frontiers in Forests and Global

Change

Received: 16 December 2018 Accepted: 09 August 2019

Published: 28 August 2019

Citation:

Cole LES, Bhagwat SA and Willis KJ

(2019) Fire in the Swamp Forest: Palaeoecological Insights Into Natural and Human-Induced Burning in Intact Tropical Peatlands.

Front. For. Glob. Change 2:48, doi: 10.3389/ffgc.2019.00048
Tropical peat swamp forests are invaluable for their role in storing atmospheric carbon, notably in their unique below-ground reservoirs. Differing from terra firme forests, the peat-forming function of tropical swamps relies on the integrity of discrete hydrological units, in turn intricately linked to the above-ground woody, and herbaceous vegetation. Contemporary changes at a local, e.g., fire, to global level, e.g., climatic change, are impacting the integrity, and functioning of these ecosystems. In order to determine the level of impact and predict their likely future response, it is essential to understand past ecosystem disturbance, and resilience. Here, we explore the impact of burning on tropical peat swamp forests. Fires within degraded tropical peatlands are now commonplace; whilst fires within intact peat swamp forests are thought to be rare events. Yet little is known about their long-term natural fire regime. Using fossil pollen and charcoal data from three peat cores collected from Sarawak, Malaysian Borneo, we looked at the incidence and impact of local and regional fire on coastal peat swamp forests over the last 7,000 years. Palaeoecological results demonstrate that burning has occurred in these wetland ecosystems throughout their history, with peaks corresponding to periods of strengthened ENSO. However, prior to the Colonial era c. 1839 when human presence in the coastal swamp forests was relatively minimal, neither local nor regional burning significantly impacted the forest vegetation. After the mid-nineteenth century, at the onset of intensified land-use change, fire incidence elevated significantly within the peatlands. Although fire does not correlate with past vegetation changes, the long-term data reveal that it likely does correlate with the clearance of forest by humans. Our results suggest that human activity may be strongly influencing and acting synergistically with fire in the recent past, leading to the enhanced degradation of these peatland ecosystems. However, intact tropical peat swamp forests can, and did recover from local fire events. These findings support present-day concerns about the increase in fire incidence and combined impacts of fire, human disturbance and El Niño on peat swamp forests, with serious implications for biodiversity, human health and global climate change.

Keywords: disturbance, fire, human impact, palaeoecology, peat swamp forests, resilience, tropical peatlands, vegetation change 


\section{INTRODUCTION}

Tropical peatlands constitute one of the most effective mediums through which we can mitigate the ongoing global rise in carbon emissions (Page et al., 2011; Lawson et al., 2015). This is only the case however, if these peatlands are in an intact state (Dommain et al., 2014). The peat swamp forests of Southeast Asia, covering an area of 25 million ha (Page et al., 2011), hold c. 12\%, some 69 Giga tons, of the total carbon stored in the world's peatlands (Page et al., 2011). The performance of these peat swamps as a carbon sink relies on a tight interrelationship between the landscape, vegetation, and hydrological conditions (Page et al., 1999; Dommain et al., 2010; Posa et al., 2011), making the forest component of this ecosystem vital for its maintenance.

Tropical peat swamp forests are formed in environments where water-logged conditions develop, coupled with high humidity (Liong and Siong, 1979; Andriesse, 1988; Dommain et al., 2014). Waterlogging creates an anaerobic environment, in which limited decomposition can occur, resulting in an accumulation of layers of leaves, and woody matter from the resident vegetation. Though not restricted to low-lying areas, coastal peat domes are common across Southeast Asia (Dommain et al., 2011). Their development is thought to have started c. 7000 Cal. year BP (Dommain et al., 2014), after the midHolocene sea-level highstand, prior to sea-level fall and coastal progradation (Dommain et al., 2011).

These coastal peat swamp forests provide multiple ecosystem services to many different communities. At a global level, they are hugely important for their carbon storage and sequestration potential (Dommain et al., 2014); the peat swamp forests of Malaysia store 9.1 Giga tons of carbon, c. 2\% of the volume globally stored in peat despite comprising $<1 \%$ of the global area (Page et al., 2011), and have been sequestering it for thousands of years (Dommain et al., 2011, 2014). With much of the region's lowland forest habitat of mineral soils having already been converted into agriculture or other uses (Miettinen et al., 2016), the peat swamp forests also act as a refuge for a vast array of flora and fauna (Yule, 2010), and a primary habitat for specially-adapted species, such as blackwater fish (Thornton et al., 2018).

Despite this, peat swamp forests are being lost at a rapid pace: in Southeast Asia between 2000 and 2010, 56\% were converted to plantations (Miettinen et al., 2012b), in addition to the area lost through logging and other development (Koh et al., 2011). In particular, fire is considered one of the most important drivers of land-use change and vast areas of these tropical peat swamps burn every year (Razali et al., 2010; Phua et al., 2012; Gaveau et al., 2014), especially on the island of Borneo (Langner and Siegert, 2009; Hoscilo et al., 2011; Miettinen et al., 2016).

Burning has increasingly affected the peat swamp forests of Southeast Asia in the last 2 to 3 decades (Taylor, 2010) and is now claimed to be one of the most profound threats to peatland habitats (Lee, 2000; Razali et al., 2010), as well as to all rainforest ecosystems (Laurance, 2003). However, natural fires, predominantly caused by lightning strikes, have constituted an important part of the ecosystem dynamics in these tropical peat swamps (Taylor et al., 2001) by creating gaps in which succession can occur. A study on peat swamp forests in Western Kalimantan suggests that fire has been a component of the landscape for at least the last 30,000 years (Anshari et al., 2001), and in Singapore, for the last 23,000 years (Taylor et al., 2001).

Small-scale forest burning by humans, largely as part of shifting cultivation practices (Haberle et al., 2001), has been recorded in forests in Sarawak from the early Holocene (Hunt and Premathilake, 2012). More recently however, fires are reported to have increased in frequency, magnitude, and impact in peat swamp forests in eastern Kalimantan (Hope et al., 2005), in Australasia over the last few centuries (Mooney et al., 2011), and across other areas of Southeast Asia in the last 2 or 3 decades (Taylor, 2010). How much recent fire frequency has increased relative to historical levels, and what impact it has had in shaping ecosystem dynamics in the peat swamp forests of Sarawak, is still poorly understood. These constitute important knowledge gaps for the ongoing management of fire within these peatland ecosystems, as has been proven elsewhere (Marrs et al., 2018).

This study aimed to investigate the patterns of fire, both local and regional in scale, in Sarawak's coastal peat swamp forests, using a long-term ecological approach. Three sediment sequences were extracted from peatlands on the coast of northern Borneo, where peat swamp forests dominated in the past (Cole et al., 2015), replaced now by degraded peatlands. Cole et al. (2015) demonstrated that peat swamp forest plant communities persisted for thousands of years in these locales, showing resilience through periods of climatic variability and other forms of disturbance; but that these communities have become more unstable in the recent past, coinciding with increases in indicators of human presence in the landscape. The overall objective of this paper is to explore more closely the presence, dimensions and impact of fire in these forests over the Late Holocene: to determine the change in frequency and magnitude of past burning in these (previously) intact ecosystems, infer the likely causes of any changes and examine if/how fire has influenced forest composition. Through reconstructing past burning regimes and vegetation change from these three fossil records, this work addresses three key research questions: (i) What is the natural fire regime in these swamps, and how has it changed through time?; (ii) What caused such patterns of fire in the landscape?; and (iii) How do the changing fire regimes impact the peat swamp forest vegetation? Results provide insights into past fire regimes, and their drivers, across three coastal peatland ecosystems, demonstrating the differing impacts of burning on the forest communities over time.

\section{MATERIALS AND METHODS}

\section{Data Collection}

The State of Sarawak, in northern Borneo, contains the greatest proportion of Malaysia's peat swamp forests, covering an area of approximately $3,000 \mathrm{~km}^{2}$ or $2 \%$ of the State (Miettinen et al., 2012a), and its deforested peatlands, which extend over an additional 11\% (FAO, 2012). Until recently, the peat swamp forests of Sarawak were denounced as "marginal wastelands" (Sawal, 2003), of little use except in the absence of alternative land. As such, large-scale conversion has occurred (Miettinen 


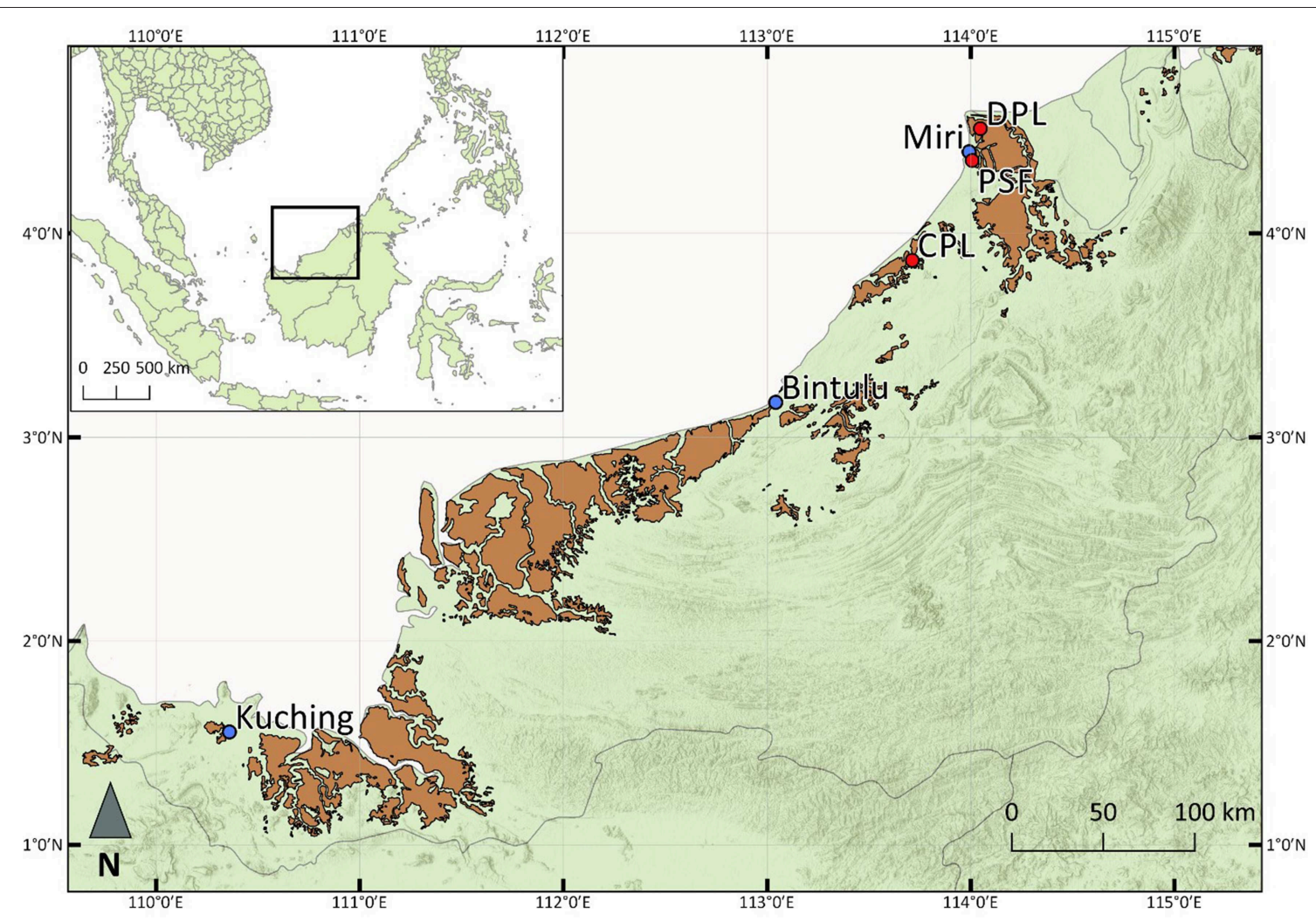

FIGURE 1 | Map showing the geographical location of Sarawak, Malaysian Borneo (inner box), within Southeast Asia, annotated with the main settlements (blue circles), and three peat swamp sites (red circles) from which cores were extracted: DPL (Deforested Peatland), PSF (Peat Swamp Fragment), and CPL (Converted Peatland). Sarawak State Boundary is demarked by a gray line; peatland areas by brown shading [courtesy of Wetlands International: "Malaysia peat lands," accessed through Global Forest Watch (www.globalforestwatch.org) (17/04/2019)].

et al., 2012b), predominantly for agricultural production (Koh et al., 2011), where fire is commonly used to clear the forest vegetation (Wooster et al., 2012).

Sedimentary cores were extracted using a hand-held coring device, from three peatlands across the Miri and Batu Niah Districts of north-east Sarawak: Deforested Peatland from Senadin, Kuala Baram $\left(04^{\circ} 30^{\prime} 47^{\prime \prime} \mathrm{N}, 114^{\circ} 2^{\prime} 47^{\prime \prime} \mathrm{E}\right)$, an area of degraded peatland covering $>50 \mathrm{~km}^{2}$; Peat Swamp Fragment from Sungai Dua Forest Reserve $\left(04^{\circ} 21^{\prime} 24^{\prime \prime} \mathrm{N}\right.$, $114^{\circ} 0^{\prime} 21^{\prime \prime} \mathrm{E}$ ), a c. $2 \mathrm{~km}^{2}$ fragment of secondary peat swamp forest; and Converted Peatland from Sungai Niah $\left(03^{\circ} 52^{\prime} 4^{\prime \prime} \mathrm{N}\right.$, $\left.113^{\circ} 42^{\prime} 43^{\prime \prime} \mathrm{E}\right)$, an agriculture-forest matrix of $c$. $1 \mathrm{~km}^{2}$ (Figures 1, 2). Though these three sampled sites cover a relatively narrow geographical range of $80 \mathrm{~km}$ along the coast of northern Borneo, since there is limited variation in climate, geology and land-use across the region, they are sufficiently representative of the coastal peat swamp ecosystems of Sarawak, and potentially those at a greater distance within insular Southeast Asia.

Using standard palaeoecological techniques (Bennett and Willis, 2001), the sediment cores were analyzed at set intervals for fossil pollen, microfossil, and macrofossil charcoal, and mineral magnetic material (magnetic susceptibility) (see Supporting Material for more information on the methods used in sediment and pollen preparation and analysis).

\section{Chronology}

To determine the age-depth relationship of the three sedimentary profiles, samples containing bulk organic material, were extracted from each peat core, prepared for ${ }^{14} \mathrm{C}$ dating and analyzed with AMS radiocarbon dating techniques, at the ${ }^{14}$ Chrono Center in the Archaeology and Palaeoecology Department, Queen's University Belfast, and the SUERC AMS Laboratory, NERC Radiocarbon Facility. (See Wust et al., 2008, for a critique of sampling techniques of tropical peat cores for radiocarbon dating). The coding package Clam (Blaauw, 2010) in R Core Team (2012), with a Northern Hemisphere correction, i.e., the IntCal04 curve, was used to calibrate the conventional radiocarbon dates, and construct the best-fitting age-depth models (see Figure S1).

\section{Reconstructing Past Burning Regimes}

A size-class analysis of fossil charcoal, i.e., differentiating between macrofossil and microfossil charcoal, was performed to investigate changes in local and regional fire regimes, respectively, in each site through time (Whitlock and Larsen, 2002). Macrofossil charcoal particles, henceforth macrocharcoal, were isolated from each $1 \mathrm{~cm}^{3}$ sample extracted for pollen analysis, by passing the sample through a $150 \mu \mathrm{m}$ sieve. This process divides the macro- and microfossil components of the sediment. The resulting macrofossil isolates were then observed 

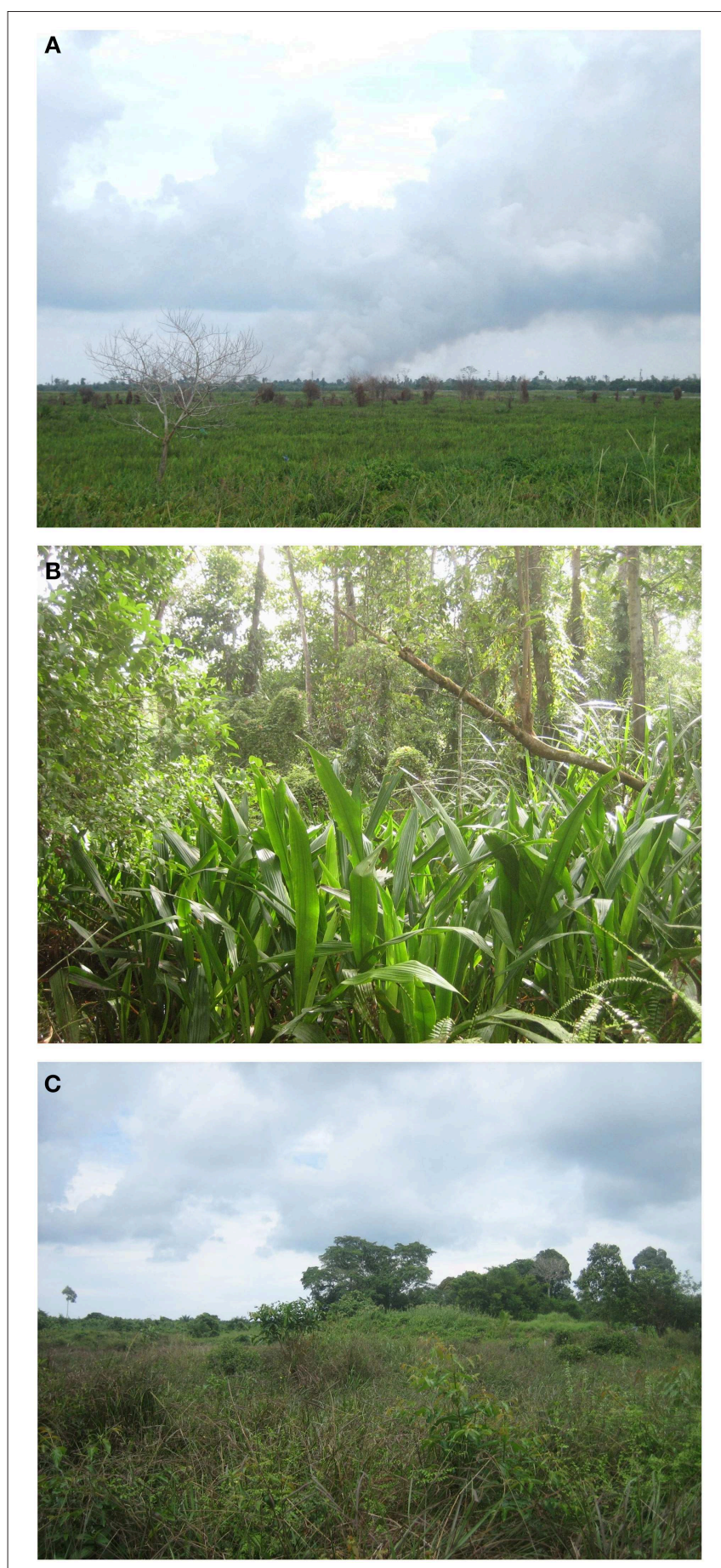

FIGURE 2 | Photographs of each study site: (A) Deforested Peatland, an area of degraded peatland covering $>50 \mathrm{~km}^{2}$ (with a fire burning in the distance when this photograph was taken); (B) Peat Swamp Fragment, a c. $2 \mathrm{~km}^{2}$ fragment of secondary peat swamp forest; and (C) Converted Peatland, an agriculture-forest matrix of c. $1 \mathrm{~km}^{2}$ (Photographs taken by L.E.S.C).

under a light microscope and the complete macrocharcoal content counted to give a measure of the number of particles per $\mathrm{cm}^{3}$ at simultaneous intervals with fossil pollen counts. Fossil charcoal particles are identifiable as black, opaque, block-shaped, and angular (Clark, 1988). The microfossil charcoal concentration, henceforth microcharcoal, was counted at the same intervals. Since microcharcoal particles are both small, i.e., $<150 \mu \mathrm{m}$, causing them to separate out with the pollen component during the sieving of samples, and resistant to the processing performed to isolate fossil pollen grains and spores, they can be counted on the same slides prepared for pollen analysis. Clark's point count method (Clark, 1982), which converts standardized count data into concentration values, measured in $\mathrm{cm}^{2} / \mathrm{cm}^{3}$, was used to quantify the microcharcoal concentration in thin section. Macrofossil charcoal is used to broadly reconstruct local fire events, since the larger charcoal particles produced during fires, i.e., those $>150 \mu \mathrm{m}$, will be heavier and less easily transported by wind or other vectors away from the burning focus, and thus concentrate around it. Whereas, microcharcoal, comprising smaller and therefore lighter charred particles, can be transported over large distances from the site of burning, and therefore signal regional fire events (Clark, 1988).

\section{Reconstructing Vegetation Change Over Time}

Due to the diversity of species in the peat swamp flora and differing levels of pollen production, and to allow for an interpretation of the palaeo-plant communities (for example Muller, 1963), taxa identified in the fossil pollen record were allocated to ecological groups (see Table S2, Supporting Material) using various publications from the region (Anderson, 1964, 1980; Stuijts, 1993; Coode et al., 1996; Anshari et al., 2001, 2004). A pollen sum was then calculated and used to estimate the relative abundance of each taxa and each ecological group through time, giving a percentage score, e.g., PSF\%. The different ecological groups are defined as follows: total PSF (TotPSF), which encompasses all peat swamp forest (PSF) associated taxa; the mature PSF community (PSF); the pioneer PSF community $(\mathrm{PSF}+)$ (indicative of transient canopy openings within a closed peat swamp forest); taxa of degraded peatlands (DP) (signaling spatially and temporally greater forest discontinuities on peat); taxa of other forests not occupying peat substrates (OF); coastal vegetation (CV) (e.g., mangroves); and Open vegetation, comprising taxa which dominate highly disturbed, open-canopied areas, for example Poaceae, Cyperaceae, and ferns (both of monolete and trilete morphologies). This latter ecological group is used as an indicator of human impact: Poaceae can be associated with human presence in forested palaeo-environments (Bush, 2002), and Cyperaceae and ferns are documented as characteristic of unmanaged degraded peatlands (Miettinen and Liew, 2010). These taxa can also produce unusually large volumes of pollen per plant, which can bias the interpretation of the vegetation composition of the landscape in palaeo studies (Bush, 2002). For this reason, and for their utility as anthropogenic indicators, Open vegetation was not included within the pollen sum but reported as a separate response variable.

Significant pollen assemblage zones were constructed using an optimal splitting by information content technique on all pollen data, after assessing the number of zones that were significant 
via a broken stick modeling approach across multiple analyses (Bennett, 1996). Psimpoll version 4.26 (Bennett, 1994) was used to display all pollen, spore, and charcoal records (Figure 3, and Figures S2, S3).

\section{Data-Handling Techniques}

In order to explore the fire regime of each core and specifically when/if peaks in fire activity have occurred through time, the macrocharcoal and microcharcoal data $(C)$, recorded as $\mathrm{cm}^{2} / \mathrm{cm}^{3}$ and particles $/ \mathrm{cm}^{3}$, respectively, were transformed to isolate such peaks from background noise. Firstly, background burning levels were assessed, and secondly, peaks in fire activity isolated from these. Prior to the transformation, both sets of data were divided by the sediment accumulation rate calculated in Clam, to produce a rate of macrocharcoal and microcharcoal accumulation through time, measured in $\mathrm{cm}^{2} /$ year and particles/year, respectively. This reduced the chances of fossil charcoal peaks in the sedimentary records being an artifact of sediment accumulation variability rather than real elevations in fire activity through time (Higuera et al., 2012). Both sets of fossil charcoal data were then resampled in the first step of the transformation, using a natural logarithm to stabilize the variance in the datasets and isolate the background fire activity, $C_{\text {back }}$, i.e., the baseline fire activity recorded in each sediment profile, using the following equation:

$$
C_{\text {back }}=\log (C+1)
$$

The second step then involved subtracting this background trend from the macrocharcoal and microcharcoal data, to create a series of residuals, i.e., peaks:

$$
C_{\text {peak }}=C-C_{\text {back }}
$$

This transformation thus provides a record of fossil charcoal fluctuation, $C_{\text {peak }}$, through time for all three sites (see Figure S2, Supporting Material), in which unusually intense burning incidences are highlighted. Although the true rate of fire events cannot be estimated due to unequal sampling intervals, episodes of increased burning frequency can be inferred where there are a greater number of elevated peaks within a period of time.

To investigate the relationship between fire and peat swamp forest vegetation through time, multivariate analyses were carried out. Principal Components Analysis (henceforth PCA) was performed in CANOCO (ter Braak and Smilauer, 2002) to explore and graphically represent the nature of the relationships between all recorded environmental variables and both internal and external peat swamp forest dynamics. Data were squareroot transformed and species scores were divided by standard deviations and scaled according to inter-species correlations. Internal dynamics are represented by changes in PSF\% and $\mathrm{PSF}+\%$, and external dynamics by the four key ecological groups in the landscape, i.e., TotPSF, DP, OF, and CV\%. To analyse the strength of the correlation between firstly fire, and secondly all environmental variables, Monte Carlo Permutation Tests were performed, using 999 restricted permutations by sample, to account for the time-series nature of the data.

\section{RESULTS}

\section{(i) What Is the Natural Fire Regime in These Coastal Peat Swamps? How Has It Changed Toward the Present Day?}

Fire has been present in all three sites through time (Figure 3, and Figure S2). Fluctuations in macrocharcoal and microcharcoal levels vary within and between cores, though there are several distinct phases of elevated magnitude and frequency of burning as follows.

\section{2,800-1,800 Cal. year BP}

Within the Peat Swamp Fragment and Converted Peatland sites, there is a coincident increase in size, i.e., magnitude, of macrocharcoal peaks, and microcharcoal for the latter site, between approximately 2,800-1,800 Cal. year BP. These magnitudes do not exceed those seen in the last 200 years however. In the Converted Peatland site the magnitude and frequency of macrocharcoal peaks and frequency of microcharcoal peaks appear to be greater prior to c. 5,000 Cal. year BP, coinciding with the local presence of a mangrove ecosystem (Figure 3). After this period, levels of macrocharcoal, and microcharcoal demonstrate very low magnitudes in all three sites until the next period of elevated burning, from c. $200 \mathrm{Cal}$. year BP.

\section{Cal. year BP to Present}

Over the last 200 years, macrocharcoal and microcharcoal levels indicate an increase in both magnitude and frequency of local and regional burning, respectively, in all three sites. These results further suggest that levels of burning exceed those seen throughout the fossil charcoal records of all cores. Microcharcoal levels in the Deforested Peatland and Peat Swamp Fragment sites, especially, greatly exceed those recorded in the past. The exception to these historically-novel elevations of fossil charcoal is in the Converted Peatland site, though not associated with a peat swamp vegetation community (Figure 3 ).

\section{(iii) How Do the Changing Fire Regimes Impact the Peat Swamp Forest Vegetation?} Peat swamp forest is considered the baseline vegetation at all three sites over the Late Holocene period, given that this ecosystem type has dominated the vegetation profiles since its development in each location. Each sediment core records a different peat development history, with Deforested Peatland having the most recently accumulated peat soils, starting from approximately 1,500 Cal. year BP; in Converted Peatland, organic matter started to accumulate in the substrate of an estuarine mangrove ecosystem several thousand years prior, though the forest associated with peat swamps did not develop until c. 2,800 Cal. year BP; and in Peat Swamp Fragment the onset of peat development arose c. 3,500 Cal. year BP (See Figure S3, for summary pollen diagrams).

Since the inferred onset of peat swamp development, the percentage of pollen from the total PSF ecological group (aggregate dark and light green components on the pollen sum diagram, Figure 3) has been relatively constant in each site 

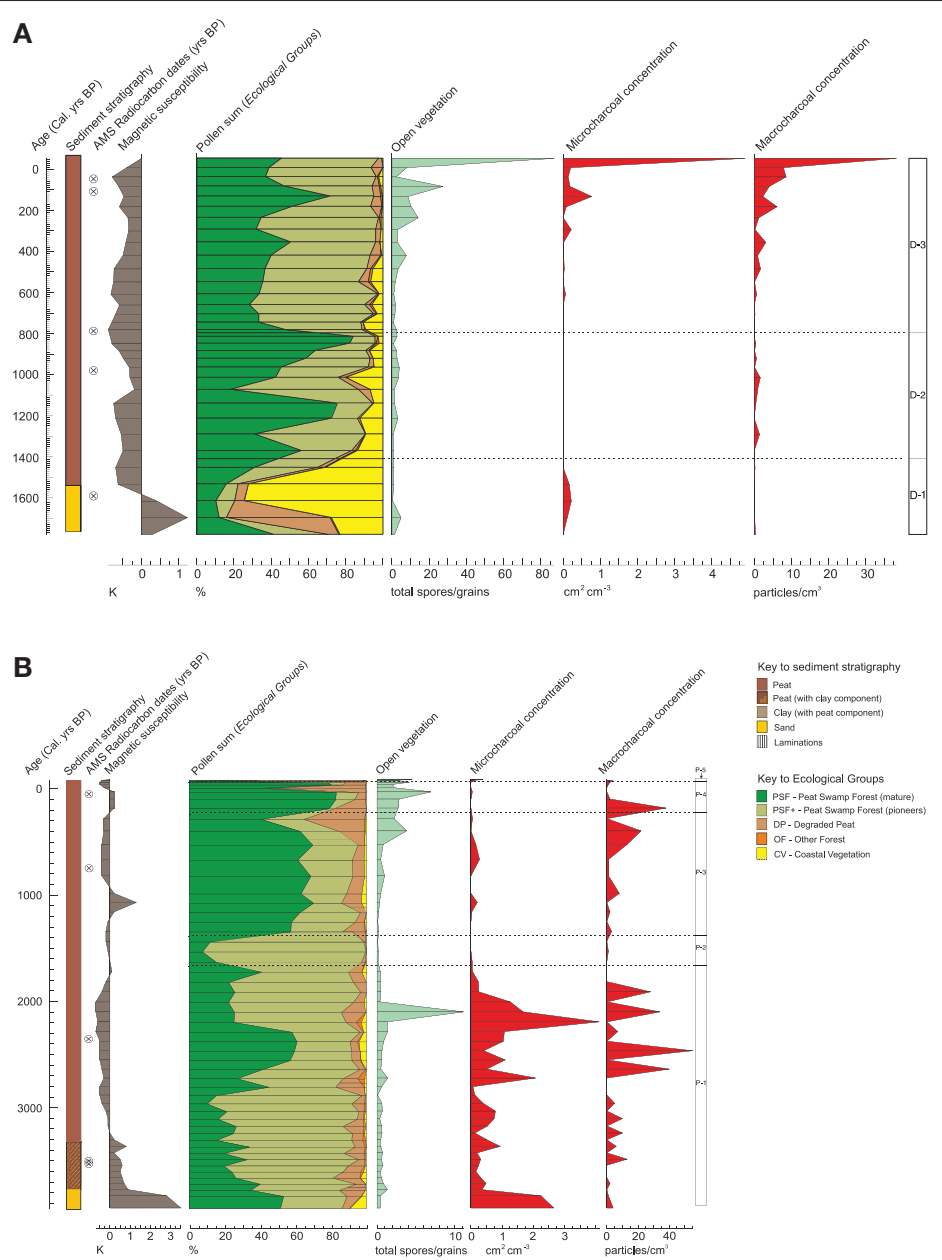

Key to Ecological Groups

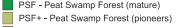

DP. Degraded Peat
OF - Orher Forest

OF- Other forest

C

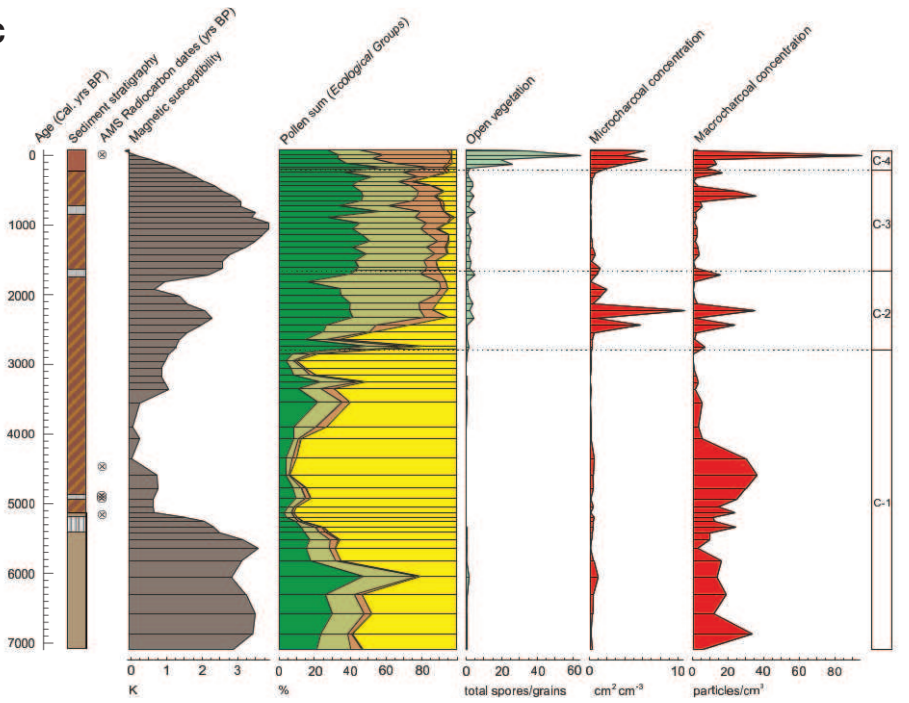

FIGURE 3 | Pollen summary diagrams for each site: (A) Deforested Peatland; (B) Peat Swamp Fragment; and (C) Converted Peatland, showing the sediment stratigraphy, magnetic susceptibility, five different ecological groups (represented by the following colors: PSF dark green, PSF+ light green, DP brown, OF orange and CV yellow), open vegetation (light gray), and macrocharcoal and microcharcoal (red). Significant pollen zones are shown for each (labeled D-, P-, and C-, respectively). TotPSF\% comprises the sum of PSF\% and PSF+\%, and is represented by the division between PSF+\% and DP\%. 
TABLE 1 | Monte Carlo Permutation Test results, performed to analyse the strength of the relationship between changes in the vegetation in each site and (a) microcharcoal and macrocharcoal, and (b) all recorded environmental variables, i.e., macrocharcoal, microcharcoal, magnetic susceptibility and open vegetation (only the strongest relationship is displayed).

\begin{tabular}{|c|c|c|c|c|c|}
\hline & Site & Environmental variable & F-statistic & $p$-value & Degrees of freedom ${ }^{\dagger}$ \\
\hline \multicolumn{6}{|c|}{ DEFORESTED PEATLAND } \\
\hline \multirow[t]{4}{*}{ (a) } & Internal & Microcharcoal & 0.14 & 0.892 & 61 \\
\hline & & Macrocharcoal & 0.82 & 0.553 & 61 \\
\hline & External & Microcharcoal & 0.57 & 0.476 & 125 \\
\hline & & Macrocharcoal & 1.77 & 0.180 & 125 \\
\hline \multirow[t]{2}{*}{ (b) } & Internal & Magnetic Susceptibility & 6.28 & 0.078 & 61 \\
\hline & External & Magnetic Susceptibility & 12.75 & 0.094 & 125 \\
\hline \multicolumn{6}{|c|}{ PEAT SWAMP FRAGMENT } \\
\hline \multirow[t]{4}{*}{ (a) } & Internal & Microcharcoal & 1.75 & 0.482 & 99 \\
\hline & & Macrocharcoal & 0.74 & 0.477 & 99 \\
\hline & External & Microcharcoal & 3.51 & 0.142 & 101 \\
\hline & & Macrocharcoal & 0.55 & 0.527 & 101 \\
\hline \multirow[t]{2}{*}{ (b) } & Internal & Open vegetation & 4.21 & 0.155 & 99 \\
\hline & External & Microcharcoal & 3.51 & 0.142 & 101 \\
\hline \multicolumn{6}{|c|}{ CONVERTED PEATLAND } \\
\hline \multirow[t]{4}{*}{ (a) } & Internal & Microcharcoal & 2.04 & 0.097 & 117 \\
\hline & & Macrocharcoal & 1.66 & 0.685 & 117 \\
\hline & External & Microcharcoal & $6.08^{*}$ & 0.014 & 237 \\
\hline & & Macrocharcoal & 0.84 & 0.723 & 237 \\
\hline \multirow[t]{2}{*}{ (b) } & Internal & Magnetic Susceptibility & 15.59 & 0.262 & 117 \\
\hline & External & Open vegetation & $9.55^{\star}$ & 0.015 & 237 \\
\hline
\end{tabular}

*Significant relationship at $p<0.05$ level.

${ }^{\dagger}$ Number of sampled sediment levels per core: Deforested peatland, 33; Peat swamp fragment, 52: Converted Peatland, 61.

The vegetation is split into internal PSF dynamics, i.e., the most significant recorded factors associated with PSF\% and PSF+\% dynamics, and external landscape dynamics, i.e., factors most strongly linked with changes in all ecological groups in the landscape (TotPSF, DP, OF, and CV\%). [999 restricted permutations by sample (allowing a time-series analysis) were used to calculate F-statistics and p-values].

through time, fluctuating c. $80 \%$. However, in the Peat Swamp Fragment and Converted Peatland sites, the total PSF proportion declines in the last $c .500$ years. The indicator group for turnover within the peat swamp forest, PSF+, does not appear to follow a pattern within or across sites, thus demonstrating internal dynamism throughout the past. Open vegetation levels in all sites remain low until c. 200 Cal. year BP, with the exception of an anomalous peak in the Peat Swamp Fragment prior to 2,000 Cal. year BP. This notable increase in open vegetation taxa suggests that there was a higher incidence of open-canopied areas in the vicinity of these sites in the last several 100 years.

Both internal peat swamp forest dynamics and external landscape change do not appear to correlate with fire, whether local or regional in scale (Table 1). The exception is the relationship between microcharcoal and external ecological change in the Converted Peatland site. Here, regional burning is correlated with vegetation fluctuations in the wider landscape ( $F$-statistic $=6.08, p$-value $=0.014)$ : as microcharcoal levels increase, the degraded peat ecological group $(D P)$, and to an extent non-PSF-related forest taxa $(O F)$, increase (Figure 4C). In terms of other environmental variables, the peat swamp forest and landscape vegetation within the Deforested Peatland site appears to correlate most with magnetic susceptibility changes, and in the Peat Swamp Fragment with changes in open vegetation and regional fire, albeit all non-significantly. In the Converted Peatland site, PSF dynamics had the strongest association with magnetic susceptibility, and landscape dynamics were significantly correlated with changes in open vegetation $(F$-statistic $=9.55, p$-value $=0.015)$.

Despite each core exhibiting different ecological patterns, one key trend is visible from the ordination diagrams: increases in open vegetation are correlated in all three sites with the pollen samples counted within the last c. 200 years (see circled clusters, Figure 4). In the Converted Peatland and Peat Swamp Fragment cores, the degraded peat ecological group is also associated with this recent landscape trend, and across all sites, Trema (Cannabaceae), increases during this period (see Figure S3, Supporting Material).

\section{DISCUSSION}

This investigation has provided novel insights into the local to regional patterns of past burning across three peatland sites over the Late Holocene, the potential drivers of this pattern and its influence on the peat swamp forest vegetation. Fossil charcoal analysis found there to be no consistent fire regime across the three studied peat swamp forest ecosystems on the coast of Sarawak over the last 2,000-7,000 years. Palaeoecological results also demonstrate that fire has not had a significant impact 

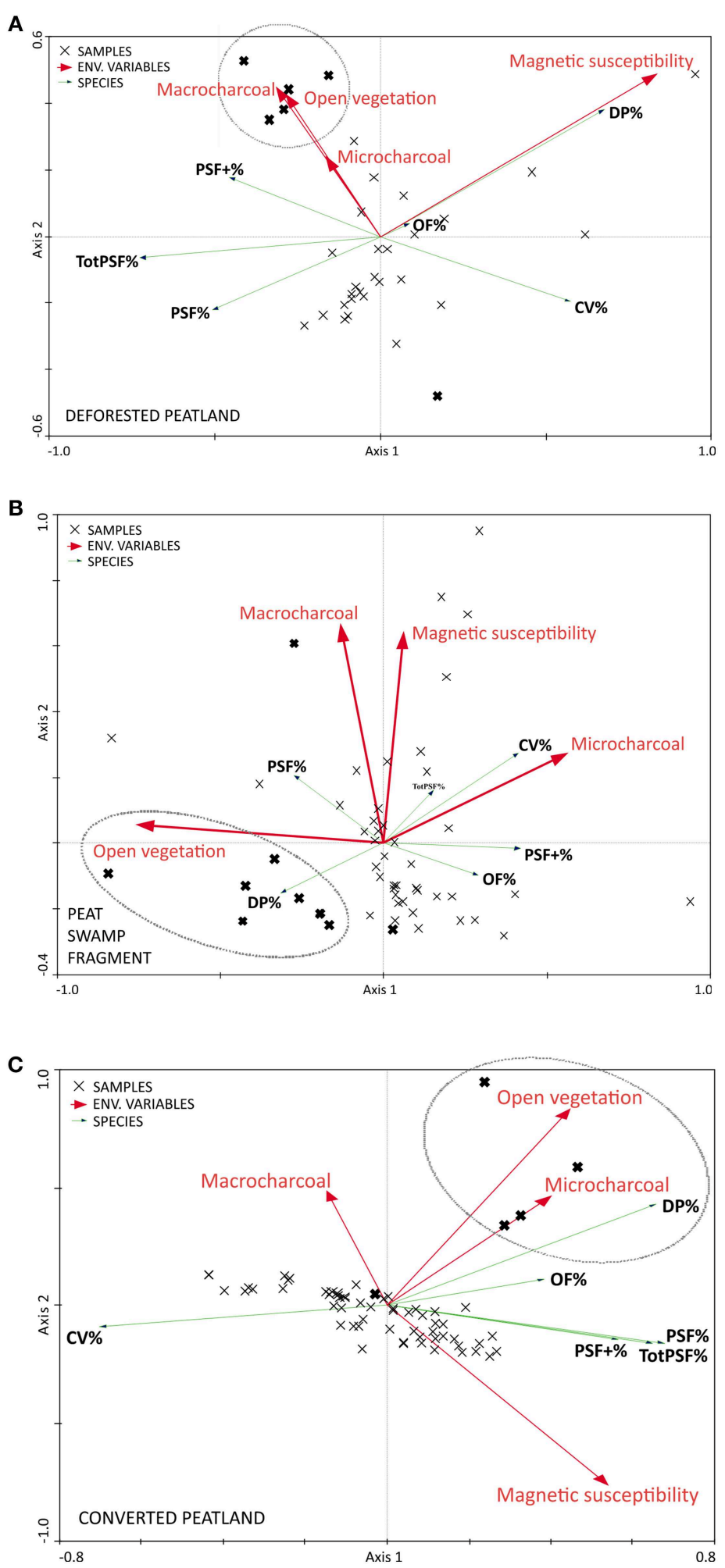

FIGURE 4 | PCA Ordination diagrams for coring sites (A) Deforested Peatland, (B) Peat Swamp Fragment, and (C) Converted Peatland, showing the relationships between the recorded environmental variables (i.e., macrocharcoal, microcharcoal, magnetic susceptibility, and open vegetation), and temporal changes in (i) internal PSF dynamics: mature (PSF\%), and pioneer PSF taxa (PSF+\%), and (ii) external landscape dynamics: the ecological groups comprising total PSF (TotPSF\%), degraded peat (DP\%), other forest (OF\%), and coastal vegetation (CV\%). In (A), the 1st axis of the ordination explains $33.3 \%$ of the variance in the distribution of the ecological groups and the 2nd axis, 4.4\%; with the inclusion of environmental variables, this percentage variance accounted for by the 1 st and 2 nd axes becomes 
FIGURE 4 | 87.1 and $11.4 \%$, respectively. In (B), $11.3 \%$ variance is attributed to the 1 st axis and $2.2 \%$ to the 2 nd axis, with the explained variance increasing to 79.5 and $15.4 \%$, respectively, when environmental variables are accounted for in the assessment of directional distribution of taxa. In (C), 43.9 and $3.1 \%$ are due to the 1 st and 2nd axes, and 93.1 and 6.6\%, respectively, when environmental variables are included. As Table 1 demonstrates, only microcharcoal and open vegetation are significantly correlated with external landscape dynamics in the Converted Peatland site. All samples dated within the last 200 Cal. year BP have been highlighted (represented by a thicker cross), and encircled where they have a notable association with environmental variables, i.e., predominantly open vegetation.

on either internal peat swamp forest vegetation communities or ecological change within the wider landscape through time. Rather, patterns of burning appear to be predominantly idiosyncratic and drivers of vegetation change predominantly anthropogenic, influenced by changes in the political, social, and economic environment of the region in the last two millenia.

\section{(i) What Is the Natural Fire Regime in These Coastal Peat Swamps? How Has It Changed Toward the Present Day?}

Results from this study demonstrate the presence of fire, to some degree, throughout the past within these coastal peat swamp forests, in accordance with findings from elsewhere in the region (Anshari et al., 2001; Taylor et al., 2001). However, there is no apparent "natural" or predictable baseline for the local or regional burning regime. Instead, evidence suggests that there were two notable episodes of increased fire across sites, overlaying a background of heterogeneity. In line with other studies, there are lengthy periods, for example between $c .1,800-$ $500 \mathrm{Cal}$. year BP, where fire frequency and magnitude appear to be low. Hope et al. (2005) found that fire was a rare occurrence in peat swamp forest at a distance from rivers before 3,000 years ago, and from contemporary work, Miettinen et al. (2012c), and Cattau et al. (2016) report the near absence of burning in intact peat swamp forests in Sumatra and Kalimantan, respectively. The large elevation in local and, to an extent, regional burning in the Converted Peatland site prior to 5,000 Cal. year BP can likely be explained by the existence of an estuarine ecosystem during that period. It is probable that charcoal from extra-local fires was washed in with tidal currents and accumulated in the mangrove muds (a process enabling both micro- and macro-sized particles to travel and become deposited), since past mangrove ecosystem dynamics are not strongly associated with fire (e.g., Alongi, 2008). Thus, these earlier elevated levels of burning are likely associated with tidally-influenced mangrove communities, rather than peat swamp forests.

Two episodes where considerable coherence and elevation in the fossil charcoal records do occur across sites, suggestive of increased regional burning, or pervasive landscape change, are as follows: the first between approximately 2,800-1,800 Cal. year $\mathrm{BP}$, and the second, within the last 200 years. In order to explore the factors that could have influenced these fire patterns over the Late Holocene, records of regional climate and information on local anthropogenic land-use change were sourced.

\section{(ii) What Caused Such Patterns of Fire in This Landscape?}

In general, climate did not appear to have a significant impact on the burning regime in any of the three sites through time.
However, the first simultaneous episode of elevated local and regional burning observed between c. 2,800-1,800 Cal. year $\mathrm{BP}$, coincides with a period of climatic drying in the Tropics that is reported to occur in the interval 2,000-3,000 Cal. year BP (Woodroffe et al., 2003; Selvaraj et al., 2007) (Figure 5). Anshari et al. (2001) report a similar increase in microfossil charcoal particles during this period, in a peat core extracted from West Kalimantan, and suggest that increased ENSO-related climatic variability may have been one reason for such an increase, predominantly through causing stress to previously stable ecosystems. They also refer to human disturbance as a potential driving force for greatly elevated charcoal to pollen ratios recorded from c. 1,400 year BP (Anshari et al., 2001).

In order to assess the probable anthropogenic influence on burning regimes in the coastal peat swamp forests studied here, there is a complex history of human-environment interactions (Figure 5) that warrants consideration. Evidence for the first human presence in northern Borneo comes from a "Deep Skull" found in the Niah Caves in northeast Sarawak, which has been dated to over 35,000 Cal. year BP (Barker et al., 2007). Other work suggests that people have been living in this area for even longer (Hunt and Premathilake, 2012), and using fire to clear forest vegetation (Hunt and Rushworth, 2005). During the late Pleistocene and much of the Holocene, low-density human communities in Borneo would have had limited impact on their densely-forested environment, and their activities, predominantly as hunter-gatherers and shifting cultivators, are unlikely to have extended far beyond the edges of peat domes, or from river-based transport networks (Hope et al., 2005). Large-scale landscape modification started to happen with the establishment of Colonial rule. Captain James Brooke, the first Viceroy of Sarawak, landed on Borneo's shores in 1839, and proceeded to organize her politics and landscape. Captain Brooke's goals were to improve levels of peace amongst the resident communities and to increase the productivity of the land (MacDonald, 1956). Fire would have played an important role in this strategic landscape conversion. At this time, people searched for land on which to farm and secure rights, in some cases turning to the relatively under-exploited peat swamps. Interview data suggests that people began living in these areas from $c .1850$, but the majority settled in peatlands much later, i.e., the early 1970s (Cole, 2013). Approximately 100 years after the first settlement, mechanization had drastically increased, along with the wealth and population of the State; developing this waterlogged "wasteland" on a large scale became both more feasible and more financially rewarding. Selective logging in the coastal peat swamps started in the early 1950s and constituted a key income for the State for 20 years. It continues today, although with declining extraction rates due to the much-depleted tree stocks. Prior to the Environmental Quality Act of 1974 (Dolmat, 


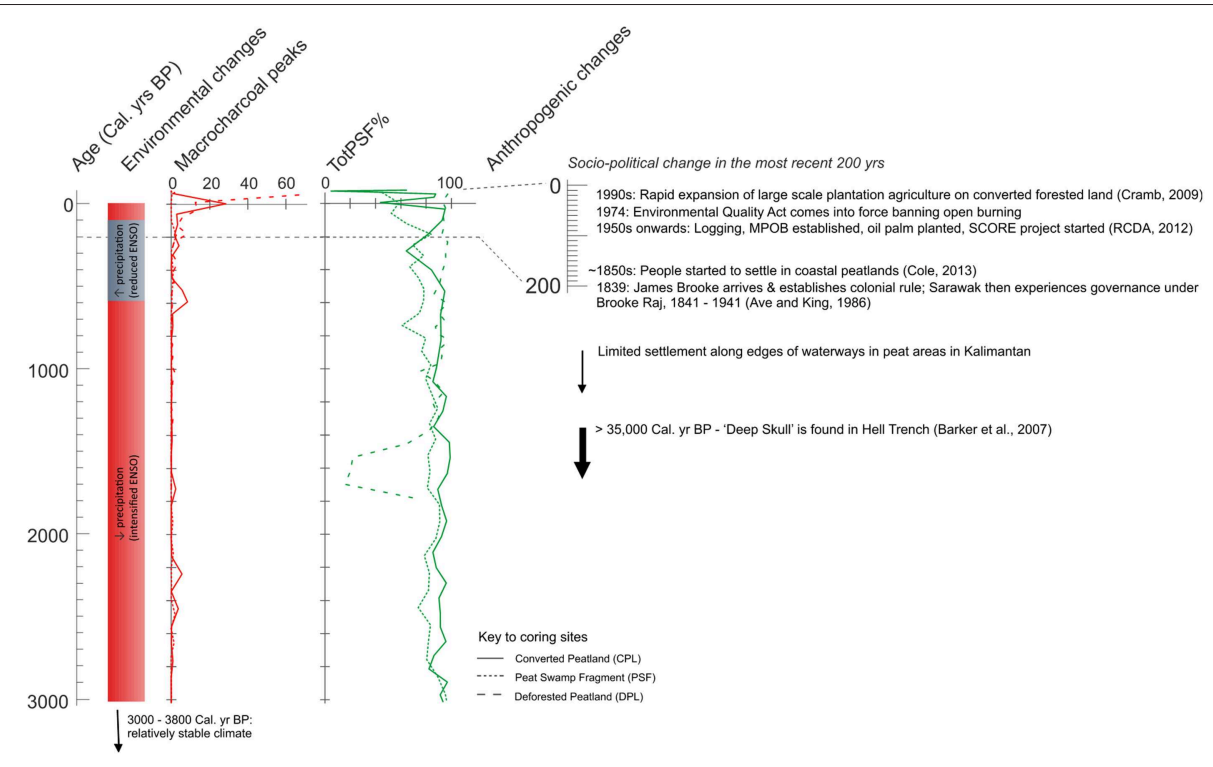

FIGURE 5 | Composite diagram illustrating the environmental, anthropogenic, and peat swamp forest ecological changes occurring within the study region over the last 3,000 years, from the first distinct phase of elevated burning across two sites (CPL and PSF, Figure 3). Historical and climatic drivers of past fire incidence within Sarawak's coastal peatlands have been identified through a literature search and interviews (Cole, 2013), with the most recent 200 years hosting a period of significant socio-political change. Variability in macrocharcoal peaks $\left(C_{\text {peak }}\right.$, measured in peak component charcoal accumulation rate (cm $\left.{ }^{3} / y r\right)$, see Figure 2 , Supporting Material) and TotPSF\% (percentage of pollen sum) across all cores are represented on separate axes, aligning with one chronological scale. (For more information on: ENSO variability, see Table S3, Supporting Material; and the history of political development in Sarawak, see (Cramb et al., 2009) and references therein).

2005), open burning to clear peat swamp forest was legal, and thus would have been used extensively by smallholder and plantation farmers. After this time, only small controlled burns were permitted by the Department of the Environment, and clearance fires were replaced by large machinery that also drained, compressed and piled peat in preparation for the establishment of oil palm and pulpwood plantations, amongst other land uses. Such modification of the land, in particular the drying caused by drainage, makes peatlands more vulnerable to fire (Page et al., 2002; Hoscilo et al., 2011; Taufik et al., 2018), whether ignited by natural or anthropogenic sources (Cattau et al., 2016).

Until several 100 years ago, local fires (those within peat swamp forest) would predominantly have been driven by natural disturbances such as lightning strikes, especially during dry climatic periods, i.e., El Niño years (Hope et al., 2005). Human disturbance would have been minimal (Sawal, 2003), restricted to activities such as subsistence sago cultivation: a crop that grows well on marginal lands (Donner, 1987). Within the last 200 years however, the coincidence of data showing dramatic increases in the magnitude and frequency of local and regional fire (and open areas), with the reporting and documenting of increased human interaction with Sarawak's coastal peat swamp forests, suggests that humans were responsible for these elevations in burning. Significant landscape exploitation by people is likely to have started after Colonial Rule was established in Sarawak approximately 170 years ago. The following quote, attributed to the Second Raj of Sarawak, Charles Brooke, in 1867, illustrates the attitude toward "idle" forested land that would have driven large-scale landscape conversion: "[We want] to see the jungle falling left and right and people settled over what are now lonely wastes and turning them into cultivated land." The dramatic recent increase in burning peatlands has also been recorded in Sumatra (Miettinen et al., 2012c) and across Southeast Asia (Van Eijk et al., 2009; Dohong et al., 2017).

\section{(iii) How Do the Changing Fire Regimes Impact the Peat Swamp Forest Vegetation?}

Results from this study suggest that fire has not caused significant disturbance to these three coastal peat swamp forests through time. Even during episodes of elevated burning in the past, for example during the inferred dry phase between c. 2,800-1,800 Cal. year BP, there is no decline in the peat swamp forest or apparent impact on the vegetation within these ecosystems. In terms of internal peat swamp forest dynamics through time, the fluctuation between mature and pioneer taxa does not correlate with fire incidence, again suggesting that, in general, burning has not played a significant role in the regeneration of these ecosystems. Since anthropogenic burning is hypothesized to have only started in the last two centuries, it appears that the natural burning regimes in each site, which have been predominantly idiosyncratic, have not had a significant negative impact on these peat swamp forests. An exception to this appears in the results of the Converted Peatland site, where regional fire appears to have a significant impact on peat swamp forest ecosystem abundance within the wider landscape. Further sampling is required to decipher reasons for this unusual finding in the Converted Peatland site.

In contrast to the long-term burning and peat swamp forest vegetation dynamics, as levels of local and regional fire 
elevate to historically-novel levels in the most recent past, declines in peat swamp forest within the landscape and an apparent lack of regeneration within the forests, suggests fire is now impacting on these ecosystems. However, the most influential drivers of peat swamp forest change across sites appear to be disturbances associated with anthropogenic activity: open vegetation, signifying forest clearance, and magnetic susceptibility, indicating disturbance and/or drying in the peat substrate. These relationships are strongest in the recent past (Figure 4), coinciding with and, most probably, driving the large elevations in local and regional fire, as suggested by other studies in this region (Lee, 2000; Langner and Siegert, 2009; Van Eijk et al., 2009). Despite these associations between peat swamp forest and environmental variables, it is important to note that the only significant relationship observed in this study occurs between open vegetation and external landscape change, i.e., a decline in peat swamp forest, in the Converted Peatland site. Further evidence for the predominantly anthropogenic origin of fire within peat swamp forest in the last 200 years, is the coincident increase in ferns, Poaceae and other nonwoody taxa of open areas (Hoscilo et al., 2011), such as Trema (Cannabaceae). This plant has been associated with the creation of gaps within the peat swamp forest greater than those resulting from local disturbances (Flenley and Butler, 2001), such as windthrow (Anderson, 1964).

In conjunction, the results from the three studied sediment cores strongly suggest that fire has been present in tropical peat swamp forests for thousands of years and that it is not the most prominent driver of long-term or recent changes in coastal peat swamp forest vegetation, contrary to the common concern expressed in the literature on the sustainable management of tropical peat swamp forests today (for example Razali et al., 2010; Miettinen et al., 2012c). Instead, human impact has had the most influence on internal peat swamp forest dynamics and peat swamp forest decline: with this disturbance manifesting only in the last c. 200 years and at unprecedented levels when compared to the last 7,000 years. In reality, it is likely that various forms of human disturbance, notably forest clearance, drainage and fire, occur simultaneously and act synergistically in these landscapes, exacerbating impacts, reducing forest regeneration potential and thus jeopardizing the resilience of these peat swamp forests.

To explore the relationship between fire, its drivers and vegetation change at a higher temporal resolution, further sampling, and the use of additional proxies, would be required. Though individual fire events can be identified from fossil charcoal records extracted from peat deposits, palaeoecological data is best suited to identifying historical trends in fire regimes (Remy et al., 2018). Observing a true response of the vegetation to an incidence of burning, or another form of disturbance, can also be challenged by differing rates of pollen production amongst species and varying distances over which pollen grains are transported, in turn affected by the changing characteristics of the canopy around the coring site, amongst other constraints (Davies et al., 2018). Signals of regional burning can, in particular, be affected by canopy cover, since microcharcoal particles can be caught in the vegetation overlying the forest floor; this can reduce the volume of microcharcoal that is found in sediment profiles causing potential under-estimations of fire incidence and intensity at a regional scale. However, this potential underestimation is not considered a significant obstacle in this and other palaeo-environmental reconstructions in tropical peatland ecosystems (e.g., Hope et al., 2005). Due to these various factors, interpretations of the data reported in this study have been limited to broad trends, and thus give an impression of ecosystem level sensitivity to burning during the Late Holocene.

Despite the limitations of long-term ecological studies, the insights gained through these data greatly extend our ability to understand the ecological functioning of ecosystems (Willis et al., 2010; Cole et al., 2015), particularly in response to fire. The findings can be used to infer how the intact peat swamp forests, and degraded peatlands, may respond to future disturbances and thus develop informed management strategies (Davies et al., 2014). In contemporary ecosystems that now exist predominantly in a degraded state (as is increasingly the case for Southeast Asia's peat swamp forests (Murdiyarso et al., 2009), long-term ecological data also enable us to define the parameters, and resilience, of their intact condition.

\section{Management Implications}

The causes of fire are complex, and include underlying cultural, political and socio-economic conditions, not simply environmental factors (Stolle et al., 2003; Langner and Siegert, 2009; Carlson et al., 2012; Shimin Sze et al., 2018). However, when considering peat swamp forest management, it is important to note that degraded, in comparison to relatively intact peatlands, are more susceptible and fundamentally less resilient to fire (for example Page et al., 2002; Van der Werf et al., 2008; Wösten et al., 2008; Hoscilo et al., 2011). The interaction between different drivers of disturbance requires further investigation when considering management interventions. This study has demonstrated however, that recent forms of anthropogenic disturbance, likely driving elevated incidences of burning, are unprecedented in the ecological history of these ecosystems.

Draining and/or forest clearing, which accompanies the majority of peat swamp forest land-use change, leads to highly flammable conditions, and inevitably subsidence (Hooijer et al., 2011) and ongoing carbon emissions (Wijedasa et al., 2018). This often results in peatlands becoming "unmanaged wastelands" or entirely converted to agriculture (Miettinen et al., 2012b). Restoration of such areas is being attempted in peatlands in Central Kalimantan (Page et al., 2009) and across Indonesia (BRG, 2018), but unless these areas are protected against fire, notably through re-wetting (Dommain et al., 2010), restoration may prove impossible (Van Eijk et al., 2009).

Contemporary studies have shown that the impacts of local fire within peat swamp forests can be severe: once the substrate has been ignited, fires can burn both above and, devastatingly, below-ground for many months (Goldammer and Seibert, 1989; Goldammer, 1992; Saharjo and Nurhayati, 2006; Posa et al., 2011), destroying meters of peat. In addition to destroying the current understory vegetation, these fires can 
hinder regeneration post-fire (Saharjo and Nurhayati, 2006; Cole, 2013), and thus reduce the possibility of future recovery, especially if soil seed banks are disturbed (Posa et al., 2011).

Unusually intense and frequent fires can also disturb natural regeneration cycles, such as those that have burnt in Indonesia's inland peat swamps during the recent extreme drought events of strong El Niño years, exemplified by the 1997-1998 episode (Page et al., 2009). Biomass burning during this period released vast amounts of carbon (between 0.81 and $2.57 \mathrm{Gt}$ ) into the atmosphere (Page et al., 2002). In addition, these fires caused a host of serious health and environmental problems in the region (Marlier et al., 2013), as well as disrupting economic activity (Varma, 2003; Aiken, 2004). Although the coastal peatlands of Southeast Asia appear to have been less impacted by these climatic events in the past (Dommain et al., 2011), managing for increased fire risk during dry El Niño years [(Pan et al., 2018) and indeed non-El Niño years, with recent land-use change causing an elevation in burning uncoupled with ENSO (Gaveau et al., 2014)], may help to prevent a recurrence of these disastrous effects in the future (Phua et al., 2007, 2012). Fire risk mapping, looking at impacts of infrastructure, for example roads and settlement, may also help (Razali et al., 2010; Shimin Sze et al., 2018), since historical fire incidence in peatlands in Kalimantan has been associated with accessibility (Hope et al., 2005). Furthermore, if the international mechanisms being developed to encourage countries to reduce their carbon emissions through forest conservation, such as the Reducing Emissions from Deforestation and Degradation (REDD+) scheme (FAO, 2012), are to include tropical peat swamp forests, the huge volumes of carbon gases released from peat fires will need to be abated (Murdiyarso et al., 2010).

At present, large scale burning of tropical peat is largely confined to Indonesia, but tropical peatlands are not only found in Southeast Asia: vast areas have recently been mapped in the Peruvian Amazon (Draper et al., 2014) and the central Congo Basin (Dargie et al., 2017). Currently, these ecosystems are largely intact and as such of huge global significance (Watson et al., 2018); but this could change if they are not protected from the

\section{REFERENCES}

Aiken, S. R. (2004). Runaway fires, smoke-haze pollution, and unnatural disasters in Indonesia. Geogr. Rev. 94, 55-79. doi: 10.1111/j.1931-0846.2004.tb00158.x

Alongi, D. M. (2008). Mangrove forests: resilience, protection from tsunamis, and responses to global climate change. Estuar. Coast. Shelf Sci. 76, 1-13. doi: 10.1016/j.ecss.2007.08.024

Anderson, J. A. R. (1964). The structure and development of the peat swamps of Sarawak and Brunei. J. Trop. Geography 18, 7-16.

Anderson, J. A. R. (1980). A Checklist of the Trees of Sarawak. Kuching: Forest Department.

Andriesse, J. P. (1988). Nature and Management of Tropical Peat Soils. Rome: Food and Agriculture Organisation.

Anshari, G., Kershaw, A. P., van der Kaars, S., and Jacobsen, G. (2004). Environmental change and peatland forest dynamics in the Lake Sentarum area, West Kalimantan, Indonesia. J. Quat. Sci. 19, 637-655. doi: 10.1002 jqqs.879

Anshari, G. P., Kershaw, A., and Van Der Kaars, S. (2001). A late pleistocene and holocene pollen and charcoal record from peat swamp forest, Lake Sentarum multiple threats to which they could soon be exposed (Roucoux et al., 2017; Dargie et al., 2018), including the more pervasive threat of climate change (Wang et al., 2018).

If recent elevated trends in burning can be prevented, predominantly through halting forest clearance and drainage, this and other studies (e.g., Hope et al., 2005; Hapsari et al., 2018) provide evidence that peat swamp forests can recover. However, in the face of current conversion rates and future land-use planning in the region (Miettinen et al., 2012b, 2016; Gaveau et al., 2016; Wijedasa et al., 2017), potential disturbance by fire must be a central consideration in the more responsible management of these carbon-rich ecosystems.

\section{AUTHOR CONTRIBUTIONS}

LC performed data collection and analysis, designed, wrote and revised the manuscript, KW assisted with manuscript structure. KW and SB contributed to manuscript revisions.

\section{FUNDING}

This research was fully supported by a NERC Ph.D. Grant, from 2008 to 2012. The open access publication fees will be paid for by the University of St Andrews.

\section{ACKNOWLEDGMENTS}

Authors would like to thank the following people for their help and feedback on this research: Dr. Samantha Jones, Dr. Kho Lip Khoon, and several kind and honest reviewers. Authors also acknowledge NERC, the NERC Radiocarbon Dating Facility (Radiocarbon Analysis Allocation Number 1565.0411) and SUERC Dating Lab for their financial support with this project.

\section{SUPPLEMENTARY MATERIAL}

The Supplementary Material for this article can be found online at: https://www.frontiersin.org/articles/10.3389/ffgc.2019. 00048/full\#supplementary-material

wildlife reserve, West Kalimantan, Indonesia. Palaeogeo. Palaeoclimat. Palaeoecol. 171, 213-228. doi: 10.1016/S0031-0182(01)00246-2

Ave, J., and King, V. T. (1986). The People of the Weeping Forest: Tradition and Change in Borneo. Leiden: National Museum of Ethnology.

Barker, G., Barton, H., Bird, M., Daly, P., Datan, I., Dykes, A., et al. (2007). The "human revolution" in lowland tropical Southeast Asia: the antiquity and behavior of anatomically modern humans at Niah Cave (Sarawak, Borneo). J. Hum. Evol. 52, 243-261. doi: 10.1016/j.jhevol.2006.08.011

Bennett, K. D. (1994). Confidence intervals for age estimates and deposition times in late-quaternary sediment sequences. Holocene 4, 337-348. doi: 10.1177/095968369400400401

Bennett, K. D. (1996). Determination of the number of zones in a biostratigraphical sequence. N. Phytol. 132, 155-170. doi: 10.1111/j.1469-8137.1996.tb04521.x

Bennett, K. D., and Willis, K. J. (2001). “"Pollen,” in tracking environmental change using lake sediments," Volume 3. in Terrestrial, Algal and Siliceous Indicators, eds. J. Smol, H. J. B. Birks, and W. Last (London: Kluwer Academic Publishers), 5-32.

Blaauw, M. (2010). Methods and code for "classical" age-modelling of radiocarbon sequences. Quat. Geochronol. 5, 512-518. doi: 10.1016/j.quageo.2010.01.002 
BRG (2018). Mengawali Restorasi Gambut Indonesia [Beginning Restoration of Indonesia's Peatlands]. Jakarta: Badan Restorasi Gambut.

Bush, M. B. (2002). On the interpretation of fossil poaceae pollen in the lowland humid neotropics. Palaeogeogr. Palaeoclimatol. Palaeoecol. 177, 5-17. doi: 10.1016/S0031-0182(01)00348-0

Carlson, K. M., Curran, L. M., Ratnasari, D., Pittman, A. M., Soares-Filho, B. S., Asner, G. P., et al. (2012). Committed carbon emissions, deforestation, and community land conversion from oil palm plantation expansion in West Kalimantan, Indonesia. Proc. Natl. Acad. Sci. U. S. A. 109, 7559-7564. doi: 10.1073/pnas.1200452109

Cattau, M. E., Harrison, M. E., Shinyo, I., Tungau, S., Uriarte, M., and DeFries, R. (2016). Sources of anthropogenic fire ignitions on the peat-swamp landscape in Kalimantan, Indonesia. Global Environ. Change 39, 205-219. doi: 10.1016/j.gloenvcha.2016.05.005

Clark, J. S. (1982). Point count estimation of charcoal in pollen preparations and thin sections of sediments. Pollen et Spores 24, 523-535.

Clark, J. S. (1988). Particle motion and the theory of charcoal analysis: source area, transport, deposition, and sampling. Quater. Res. 30, 67-80. doi: 10.1016/0033-5894(88)90088-9

Cole, L. E. S. (2013). Disturbance, recovery and resilience in tropical forests: a focus on the coastal peat swamp forests of malaysian borneo (Doctoral thesis). Oxford: University of Oxford. Available online at: http://ora.ox.ac.uk/objects/ uuid\%3Aa135aff3-ea84-4766-8046-b3bb4ce31275

Cole, L. E. S., Bhagwat, S. A., and Willis, K. J. (2015). Long-term disturbance dynamics and resilience of tropical peat swamp forests. J. Ecol. 103, 16-30. doi: 10.1111/1365-2745.12329

Coode, M. J. E., Dransfield, J., Forman, L. L., Kirkup, D. W., and Idris, M. S. (1996). A Checklist of the Flowering Plants and Gymnosperms of Brunei Darussalam. Brunei: Darusima Trading and Printing Co.

Cramb, R. A., Pierce Colfer, C. J., Dressler, W., Laungaramsri, P., Le, Q. T., Mulyoutami, E., et al. (2009). Swidden transformations and rural livelihoods in southeast asia. Hum. Ecol. 37, 323-346. doi: 10.1007/s10745-009-9241-6

Dargie, G. C., Lawson, I. T., Rayden, T. J., Miles, L., Mitchard, E. T. A., Page, S. E., et al. (2018). Congo basin peatlands: threats and conservation priorities. Mitigat. Adapt. Strat. Global Change 24, 669-686. doi: 10.1007/s11027-017-9774-8

Dargie, G. C., Lewis, S. L., Lawson, I. T., Mitchard, E. T. A., Page, S. E., Bocko, Y. E., et al. (2017). Age, extent and carbon storage of the central congo basin peatland complex. Nature 542, 86-90. doi: 10.1038/nature21048

Davies, A. L., Colombo, S., and Hanley, N. (2014). Improving the application of long-term ecology in conservation and land management. J. Appl. Ecol. 51, 63-70. doi: 10.1111/1365-2664.12163

Davies, A. L., Streeter, R., Lawson, I. T., Roucoux, K. H., and Hiles, W. (2018). The application of resilience concepts in palaeoecology. Holocene 28, 1523-1534. doi: 10.1177/0959683618777077

Dohong, A., Aziz, A. A., and Dargusch, P. (2017). A review of the drivers of tropical peatland degradation in South-East Asia. Land Use Policy 69, 349-360. doi: 10.1016/j.landusepol.2017.09.035

Dolmat, M. T. (2005). Technologies for Planting Oil Palm on Peat. Malaysia: Malaysia Palm Oil Board.

Dommain, R., Couwenberg, J., Glaser, P. H., Joosten, H., Nyoman, I., and Suryadiputra, N. (2014). Carbon storage and release in Indonesian peatlands since the last deglaciation. Quat. Sci. Rev. 97, 1-32. doi: 10.1016/j.quascirev.2014.05.002

Dommain, R., Couwenberg, J., and Joosten, H. (2010). Hydrological self-regulation of domed peatlands in south-east Asia and consequences for conservation and restoration. Mires Peat 6, 1-17.

Dommain, R., Couwenberg, J., and Joosten, H. (2011). Development and carbon sequestration of tropical peat domes in south-east Asia: links to post-glacial sealevel changes and Holocene climate variability. Quat. Sci. Rev. 30, 999-1010. doi: 10.1016/j.quascirev.2011.01.018

Donner, W. (1987). Land Use and Environment in Indonesia. London: C. Hurst and Company.

Draper, F. C., Roucoux, K. H., Lawson, I. T., Mitchard, E. T. A., Honorio Coronado, E. N., Lähteenoja, O., et al. (2014). The distribution and amount of carbon in the largest peatland complex in Amazonia. Environ. Res. Lett. 9:124017. doi: $10.1088 / 1748-9326 / 9 / 12 / 124017$
FAO (2012). Peatlands - Guidance for Climate Change Mitigation by Conservation, Rehabilitation and Sustainable Use. Rome: Food and Agriculture Organization of the United Nations (FAO) and Wetlands International.

Flenley, J. R., and Butler, K. (2001). Evidence for continued disturbance of upland rain forest in Sumatra for the last 7000 years of an 11,000 year record. Palaeogeogr. Palaeoclimatol. Palaeoecol. 171, 289-305. doi: 10.1016/S0031-0182(01)00250-4

Gaveau, D. L. A., Sheil, D., Husnayaen, Salim, M. A., Arjasakusuma, S., Ancrenaz, M., et al. (2016). Rapid conversions and avoided deforestation: examining four decades of industrial plantation expansion in Borneo. Sci. Rep. 6:32017. doi: $10.1038 /$ srep32017

Gaveau, D. L. A., Sloan, S., Molidena, E., Yaen, H., Sheil, D., Abram, N. K., et al. (2014). Four decades of forest persistence, clearance and logging on Borneo. PLOS ONE 9:e101654. doi: 10.1371/journal.pone.0101654

Goldammer, J. G. (1992). Tropical Forests in Transition: Ecology of Natural and Anthropogenic Disturbance Processes. Basel-Boston: Birkhauser-Verlag.

Goldammer, J. G., and Seibert, B. (1989). Natural rain forest fires in eastern borneo during the pleistocene and Holocene. Sci. Nat. 76, 518-520. doi: $10.1007 / \mathrm{BF} 00374124$

Haberle, S. G., Hope, G. S., and Van Der Kaars, S. (2001). Biomass burning in Indonesia and Papua New Guinea: natural and human induced fire events in the fossil record. Palaeogeogr. Palaeoclimatol. Palaeoecol. 171, 259-268. doi: 10.1016/S0031-0182(01)00248-6

Hapsari, K. A., Biagioni, S., Jennerjahn, T. C., Reimer, P., Saad, A., Sabiham, S., et al. (2018). Resilience of a peatland in Central Sumatra, Indonesia to past anthropogenic disturbance: improving conservation and restoration designs using palaeoecology. J. Ecol. 106, 2473-2490. doi: 10.1111/1365-2745.13000

Higuera, P. E., Gavin, D. G., Bartlein, P. J., and Hallett, D. J. (2012). Peak detection in sediment-charcoal records: impacts of alternative data analysis methods on fire-history interpretations. Int. J. Wild. Fire 19, 996-1014. doi: 10.1071/WF09134

Hooijer, A., Page, S., Jauhiainen, J., Lee, W. A., Lu, X. X., Idris, A., et al. (2011). Subsidence and carbon loss in drained tropical peatlands: reducing uncertainty and implications for $\mathrm{CO}_{2}$ emission reduction options. Biogeosci. Discuss. 8, 9311-9356. doi: 10.5194/bgd-8-9311-2011

Hope, G., Chokkalingam, U., and Anwar, S. (2005). The stratigraphy and fire history of the Kutai Peatlands, Kalimantan, Indonesia. Quater. Res. 64, 407-417. doi: 10.1016/j.yqres.2005.08.009

Hoscilo, A., Page, S. E., Tansey, K. J., and Rieley, J. O. (2011). Effect of repeated fires on land-cover change on peatland in southern Central Kalimantan, Indonesia, from 1973 to 2005. Int. J. Wildland Fire 20, 578-588. doi: 10.1071/WF10029

Hunt, C. O., and Premathilake, R. (2012). Early Holocene vegetation, human activity and climate from Sarawak, Malaysian Borneo. Quater. Int. 249, 105-119. doi: 10.1016/j.quaint.2011.04.027

Hunt, C. O., and Rushworth, G. (2005). Cultivation and human impact at $6000 \mathrm{cal}$ yr B.P. in tropical lowland forest at Niah, Sarawak, Malaysian Borneo. Quater. Res. 64, 460-468. doi: 10.1016/j.yqres.2005.08.010

Koh, L. P., Miettinen, J., Liew, S. C., and Ghazoul, J. (2011). Remotely sensed evidence of tropical peatland conversion to oil palm. Proc. Natl. Acad. Sci. U.S.A. 108, 5127-5132. doi: 10.1073/pnas.1018776108

Langner, A., and Siegert, F. (2009). Spatiotemporal fire occurrence in Borneo over a period of 10 years. Glob. Chang. Biol. 15, 48-62. doi: $10.1111 / j .1365-2486.2008 .01828 . x$

Laurance, W. F. (2003). Slow burn: the insidious effects of surface fires on tropical forests. Trends Ecol. Evol. 18, 209-212. doi: 10.1016/S0169-5347(03)00064-8

Lawson, I. T., Kelly, T. J., Aplin, P., Boom, A., Dargie, G., Draper, F. C. H., et al. (2015). Improving estimates of tropical peatland area, carbon storage, and greenhouse gas fluxes. Wetlands Ecol. Manage. 23:327. doi: $10.1007 / \mathrm{s} 11273-014-9402-2$

Lee, G. (2000). "Analysis of human impact on humid, tropical forests in Jambi, Indonesia, using satellite images," in International Geoscience and Remote Sensing Symposium (IGARSS) (Honolulu, HI), 1963-1965. doi: 10.1109/igarss.2000.858202

Liong, T. Y., and Siong, K. H. (1979). A Review of Lowland Organic Soils of Sarawak. Technical Paper No. 4. Sarawak: Research Branch, Department of Agriculture.

MacDonald, M. (1956). Borneo People. London: Jonathan Cape. 
Marlier, M. E., DeFries, R. S., Voulgarakis, A., Kinney, P. L., Randerson, J. T., Shindell, D. T., et al. (2013). El Niño and health risks from landscape fire emissions in Southeast Asia. Nat. Clim. Chang. 3, 131-136. doi: $10.1038 /$ nclimate 1658

Marrs, R. H., Marsland, E.-L., Lingard, R., Appleby, P. G., Piliposyan, G. T., Rose, R. J., et al. (2018). Experimental evidence for sustained carbon sequestration in fire-managed, peat moorlands. Nat. Geosci. 12, 108-112. doi: 10.1038/s41561-018-0266-6

Miettinen, J., Hooijer, A., Wang, J., Shi, C., and Liew, S. (2012c). Peatland degradation and conversion sequences and interrelations in Sumatra. Reg. Environ. Change 12, 729-737. doi: 10.1007/s10113-012-0290-9

Miettinen, J., and Liew, S. C. (2010). Degradation and development of peatlands in Peninsular Malaysia and in the islands of Sumatra and Borneo since 1990. Land Degrad. Develop. 21, 285-296. doi: 10.1002/ldr.976

Miettinen, J., Shi, C., and Liew, S. C. (2012a). Two decades of destruction in Southeast Asia's peat swamp forests. Front. Ecol. Environ. 10, 124-128. doi: $10.1890 / 100236$

Miettinen, J., Shi, C., and Liew, S. C. (2016). Land cover distribution in the peatlands of Peninsular Malaysia, Sumatra and Borneo in 2015 with changes since 1990. Global Ecol. Conserv. 6, 67-78. doi: 10.1016/j.gecco.2016.02.004

Miettinen, J., Shi, C., Tan, W. J., and Liew, S. C. (2012b). 2010 land cover map of insular Southeast Asia in 250-m spatial resolution. Remote Sens. Lett. 3, 11-20. doi: 10.1080/01431161.2010.526971

Mooney, S. D., Harrison, S. P., and Bartlein, P. J. (2011). Late quaternary fire regimes of Australasia. Quat. Sci. Rev. 30, 28-46. doi: 10.1016/j.quascirev.2010.10.010

Muller, J. (1963). "Palynological study of holocene peat in Sarawak," in Proceedings of the Symposium of Ecological Restoration in the Humid Tropics (Kuching), 147-156.

Murdiyarso, D., Hergoualc,'H. K., and Verchot, L. V. (2010). Opportunities for reducing greenhouse gas emissions in tropical peatlands. Proc. Natl. Acad. Sci. U.S.A. 107, 19655-19660. doi: 10.1073/pnas.0911966107

Murdiyarso, D., Lilleskov, E., and Kolka, R. (2009). Tropical peatlands under siege: the need for evidence-based policies and strategies. Mitigat. Adapt. Strat. Global Chang. 24, 493-505. doi: 10.1007/s11027-019-9844-1

Page, S., Hosciło, A., Wösten, H., Jauhiainen, J., Silvius, M., Rieley, J., et al. (2009). Restoration ecology of lowland tropical peatlands in Southeast Asia: current knowledge and future research directions. Ecosystems. 12, 888-905. doi: 10.1007/s10021-008-9216-2

Page, S. E., Rieley, J. O., and Banks, C. J. (2011). Global and regional importance of the tropical peatland carbon pool. Glob. Chang. Biol. 17, 798-818. doi: 10.1111/j.1365-2486.2010.02279.x

Page, S. E., Rieley, J. O., Shotyk, Ø. W., and Weiss, D. (1999). Interdependence of peat and vegetation in a tropical peat swamp forest. Philosop. Trans. R. Soc. B. Biol. Sci. 354, 1885-1887. doi: 10.1098/rstb.1999.0529

Page, S. E., Siegert, F., Rieley, J. O., Boehm, H.-D. V., Jaya, A., and Limin, S. (2002). The amount of carbon released from peat and forest fires in Indonesia during 1997. Nature 420, 61-65. doi: 10.1038/nature01131

Pan, X., Chin, M., Ichoku, C. M., and Field, R. D. (2018). Connecting Indonesian fires and drought with the type of El Niño and phase of the Indian Ocean dipole during 1979-2016. J. Geophys. Res. 123, 7974-7988. doi: 10.1029/2018JD028402

Phua, M.-H., Tsuyuki, S., Lee, J. S., and Sasakawa, H. (2007). Detection of burned peat swamp forest in a heterogeneous tropical landscape: a case study of the Klias Peninsula, Sabah, Malaysia. Landsc. Urban Plan. 82, 103-116. doi: 10.1016/j.landurbplan.2007.01.021

Phua, M.-H., Tsuyuki, S., Soo Lee, J., and Ghani, M. A. A. (2012). Simultaneous detection of burned areas of multiple fires in the tropics using multisensor remote-sensing data. Int. J. Remote Sens. 33, 4312-4333. doi: 10.1080/01431161.2011.643460

Posa, M. R. C., Wijedasa, L. S., and Corlett, R. T. (2011). Biodiversity and conservation of tropical peat swamp forests. Bioscience 61, 49-57. doi: 10.1525/bio.2011.61.1.10

R Core Team (2012). A Language and Environment for Statistical Computing. R foundation for statistical computing, Vienna. Available online at: http://www. R-project.org (accessed December 15, 2018).

Razali, S. M., Nuruddin, A. A., Malek, I. A., and Patah, N. A. (2010). Forest fire hazard rating assessment in peat swamp forest using landsat thematic mapper image. J. Appl. Remote Sens. 4:043531. doi: 10.1117/1. 3430040

RCDA (2012). Sarawak SCORE - Corridor of Renewable Energy. Available online at: http://www.recoda.com.my/ (accessed December 15, 2018).

Remy, C. C., Fouquemberg, C., Asselin, H., Andrieux, B., Magnan, G., Brossier, B., et al. (2018). Guidelines for the use and interpretation of palaeofire reconstructions based on various archives and proxies. Quat. Sci. Rev. 193, 312-322. doi: 10.1016/j.quascirev.2018.06.010

Roucoux, K. H., Lawson, I. T., Baker, T. R., del Castillo Torres, D., Draper, F. C., Lähteenoja, O., et al. (2017). Threats to intact tropical peatlands and opportunities for their conservation. Conserv. Biol. 31, 1283-1292. doi: $10.1111 /$ cobi.12925

Saharjo, B. H., and Nurhayati, A. D. (2006). Domination and composition structure change at hemic peat natural regeneration following burning; a case study in pelalawan, riau province. Biodiversitas 7, 154-158. doi: $10.13057 /$ biodiv/d070213

Sawal, P. (2003). Threats to Peat Swamp Forest of Sarawak. Malaysia/The Netherlands Joint Working Group on Sustainable Forest Management, Kuching, Malaysia, Available online at: http://www.alterra.wur.nl/ NR/rdonlyres/78164A36-BDC0-471F-BB80-08D10A55F689/135280/ JWGRAM05.pdf (accessed 2012).

Selvaraj, K., Chen, C. T. A., and Lou, J.-Y. (2007). Holocene East Asian monsoon variability: links to solar and tropical Pacific forcing. Geophys. Res. Lett. 34:L01703. doi: 10.1029/2006GL028155

Shimin Sze, J., Jefferson, J., and Lee, J. S. H. (2018). Evaluating the social and environmental factors behind the 2015 extreme fire event in Sumatra, Indonesia. Environ. Res. Lett. 14:015001. doi: 10.1088/1748-9326/aaee1d

Stolle, F., Chomitz, K. M., Lambin, E. F., and Tomich, T. P. (2003). Land use and vegetation fires in Jambi Province, Sumatra, Indonesia. For. Ecol. Manage. 179, 277-292. doi: 10.1016/S0378-1127(02)00547-9

Stuijts, I.-L. M. (1993). Late Pleistocene and Holocene Vegetation of West Java, Indonesia, (Doctoral thesis) Rotterdam, Netherlands.

Taufik, M., Setiawan, B. I., and Van Lanen, H. A. J. (2018). Increased fire hazard in human-modified wetlands in Southeast Asia. Ambio. 48, 363-373. doi: $10.1007 / \mathrm{s} 13280-018-1082-3$

Taylor, D. (2010). Biomass burning, humans and climate change in Southeast Asia. Biodivers. Conserv. 19, 1025-1042. doi: 10.1007/s10531-009-9756-6

Taylor, D., Yen, O. H., Sanderson, P. G., and Dodson, J. (2001). Late quaternary peat formation and vegetation dynamics in a lowland tropical swamp; Nee Soon, Singapore. Palaeogeogr. Palaeoclimatol. Palaeoecol. 171, 269-287. doi: 10.1016/S0031-0182(01)00249-8

ter Braak, C. J. F., and Smilauer, P. (2002). CANOCO Reference Manual and CanoDraw for Windows User's Guide: Software for Canonical Community Ordination (version 4.5). New York, NY: Microcomputer Power.

Thornton, S. A., Dudin, Page, S. E., Upton, C., and Harrison, M.E. (2018). Peatland fish of Sebangau, Borneo: diversity, monitoring and conservation. Mires Peat. 22, 1-25. doi: 10.19189/MaP.2017.OMB.313

Van der Werf, G. R., Dempewolf, J., Trigg, S. N., Randerson, J. T., Kasibhatla, P. S., Giglio, L., et al. (2008). Climate regulation of fire emissions and deforestation in equatorial Asia. Proc. Natl. Acad. Sci. U.S.A. 105, 20350-20355. doi: 10.1073/pnas.0803375105

Van Eijk, P., Leenman, P., Wibisono, I. T. W., and Giesen, W. (2009). Regeneration and restoration of degraded peat swamp forest in Berbak NP, Jambi, Sumatra, Indonesia. Malayan Nat. J. 61, 223-241.

Varma, A. (2003). The economics of slash and burn: a case study of the 1997/1998 Indonesian forest fires. Ecol. Econ. 46, 159-171. doi: 10.1016/S0921-8009(03)00139-3

Wang, S., Zhuang, Q., Lähteenoja, O., Draper, F., and Cadillo-Quiroz, H. (2018). Potential shift from a carbon sink to a source in Amazonian peatlands under a changing climate. Proc. Natl. Acad. Sci. U.S.A. 115, 12407-12412. doi: 10.1073/pnas.1801317115

Watson, J. E. M., Venter, O., Lee, J., Jones, K. R., Robinson, J. G., Possingham, H. P., et al. (2018). Protect the last of the wild. Nature 563, 27-30. doi: 10.1038/d41586-018-07183-6

Whitlock, C., and Larsen, C. (2002). "Charcoal as a fire proxy," in Tracking Environmental Change Using Lake Sediments: Developments in Paleoenvironmental Research, eds J. P. Smol, H. J. B. Birks, W. M. 
Last, R. S. Bradley, and K. Alverson (Dordrecht: Springer), 75-97. doi: 10.1007/0-306-47668-1_5

Wijedasa, L. S., Jauhiainen, J., Könönen, M., Lampela, M., Vasander, H., Leblanc, M., et al. (2017). Denial of long-term issues with agriculture on tropical peatlands will have devastating consequences. Glob. Change. Biol. 23, 977-982. doi: $10.1111 /$ gcb.13516

Wijedasa, L. S., Sloan, S., Page, S. E., Clements, G. R., Lupascu, M., and Evans, T.A. (2018). Carbon emissions from South-East Asian peatlands will increase despite emission-reduction schemes. Glob. Change Biol. 24, 4598-4613. doi: 10.1111/gcb.14340

Willis, K. J., Bailey, R. M., Bhagwat, S. A., and Birks, H. J. B. (2010). Biodiversity baselines, thresholds and resilience: testing predictions and assumptions using palaeoecological data. Trends Ecol. Evolut. 10, 583-591. doi: $10.1016 /$ j.tree.2010.07.006

Woodroffe, C. D., Beech, M. R., and Gagan, M. K. (2003). Mid-late Holocene El Niño variability in the equatorial Pacific from coral microatolls. Geophys. Res. Lett. 30:1358. doi: 10.1029/2002GL015868

Wooster, M. J., Perry, G. L. W., and Zoumas, A. (2012). Fire, drought and El Niño relationships on Borneo (Southeast Asia) in the preMODIS era (1980-2000). Biogeosciences 9, 317-340. doi: 10.5194/bg-9317-2012
Wösten, J. H. M., Clymans, E., Page, S. E., Rieley, J. O., and Limin, S. H. (2008) Peat-water interrelationships in a tropical peatland ecosystem in Southeast Asia. CATENA 73, 212-224. doi: 10.1016/j.catena.2007.07.010

Wust, R. A. J., Jacobsen, G. E., van der Gaast, H., and Smith, A. M. (2008). Comparison of radiocarbon ages from different organic fractions in tropical peat cores: insights from Kalimantan, Indonesia. Radiocarbon 50, 359-372. doi: $10.1017 /$ S0033822200053492

Yule, C. M. (2010). Loss of biodiversity and ecosystem functioning in Indo-Malayan peat swamp forests. Biodivers. Conserv. 19, 393-409. doi: $10.1007 /$ s10531-008-9510-5

Conflict of Interest Statement: The authors declare that the research was conducted in the absence of any commercial or financial relationships that could be construed as a potential conflict of interest.

Copyright (C) 2019 Cole, Bhagwat and Willis. This is an open-access article distributed under the terms of the Creative Commons Attribution License (CC BY). The use, distribution or reproduction in other forums is permitted, provided the original author(s) and the copyright owner(s) are credited and that the original publication in this journal is cited, in accordance with accepted academic practice. No use, distribution or reproduction is permitted which does not comply with these terms. 